\title{
Banking sector development and economic growth developing countries: A bootstrap panel Granger causality analysis
}

\author{
Khalil Mhadhbi $^{1}$. Chokri Terzi ${ }^{1}$.
}

Ali Bouchrika ${ }^{1}$

\begin{abstract}
The purpose of this paper is to revisit the Granger causal relationship between banking sector development and economic growth for forty developing countries in the period 1970-2012. In order to capture the different aspects of banking sector development, we develop two banking sector development indices and apply the panel bootstrapped approach to Granger causality testing approach properly taking into account cross-sectional dependence and heterogeneity issues. The empirical results show limited support for the supply-leading, demand-following and complementarity hypotheses. Our results also provide evidence as the causal relationship between banking sector development and economic growth exists in twenty five countries.
\end{abstract}

Keywords Economic growth . Banking sector development . Cross-sectional dependency . Slope heterogeneity. Granger causality Bootstrap

JEL Classification O43 . C22 . C23

Khalil Mhadhbi

k_mhadebi@yahoo.fr

Chokri Terzi

terisig5@yahoo.fr

Ali Bouchrika

ali.bouchrika@yahoo.fr

1 Higher Institute of Management, University of Gabes, Tunisia 


\section{Introduction}

The banking sector is an integral part of the economy. Hence this sector plays a key role in the wellbeing of the economy. A weak banking sector not only jeopardizes the long-term sustainability of an economy, it can also be a trigger for a financial crisis which can lead to economic crises. The role of banks in an economy has received attention since the 18th century (e.g. Smith, 1776; Bagehot, 1873 and Schumpeter, 1911 and 1934). Generally, the relationship between financial development and economic growth has been widely discussed in the literature since the seminal work Schumpeter (1911). Many studies (King and Levine, 1993a, b; Thornton, 1994; Gregorio and Guidotti, 1995; Berthelemy and Varoudakis, 1996; Greenwood and Bruce, 1997; Greenwood and Smith, 1997; Blackburn and Hung, 1998; Rajan and Zingales, 1998; Beck et al. 2000; Kirkpatrick, 2000; Fase and Abma, 2003; Beck and Levine, 2004; Craigwell and al. 2001; Ang, 2008a; Fung 2009; Kar et al. 2011; Murinde, 2012; Pradhan, 2013; Hsueh et al. 2013; Herwartz and Walle, 2014; Uddin et al. 2014; Menyah et al. 2014) examined the link between financial sector development and economic growth using a number of econometric techniques, such as cross-sectional, time series, panel data, firm level, industry-level and country-level.

The existing literature offers a wide range of perspectives and insights into the issue of the growth - finance nexus, which, however, sometimes report contradicting results. Bagehot (1873) and Hicks (1969) argued that financial system played a critical role in igniting industrialization in England by facilitating the mobilization of capital for "immense works". Schumpeter (1934) emphasized the importance of the banking system in economic growth and highlighted circumstances when banks can actively spur innovation and future growth by identifying and funding productive investments. With the contributions of McKinnon (1973) and Shaw (1973), the relationship between financial development and economic growth has been an important issue of debate, and during the last thirty years this relationship has been extensively studied. Recent empirical studies, however, offers contradictory evidence (Kaminsky and Reinhart, 1999; Deidda and Fattouh, 2002; Khan and Senhadji, 2003; Wachtel, 2003; Favara, 2003; Rousseau and Wachtel, 2011; Arcand et al. 2012; Al-Malkawi et al. 2012).

In response to the above focus on finance-growth nexus, this paper examines the nexus in the developing countries. In those countries, banks are the most important financial intermediaries and play an important role in bridging savings and investments. According to the results presented in the existing literature, the direction of causality between banking sector development and economic growth still remains divisive. Three different hypotheses have been proposed.

The first view is that banking sector development is supply-leading, in the banking sector development sense that it fosters economic growth by acting as a productive input. This view pioneered by Schumpeter (1911) and confirmed by notable studies such as Thornton (1994), Calderon and Liu (2003), Naceur and Ghazouani (2007), Ang (2008b), Abu-Bader and Abu-Qarn (2008), Jalil et al. (2010), Wu et al. (2010), Kar et al. (2011), Chaiechi (2012), Bojanic (2012), Hsueh et al. (2013) and Menyah et al. (2014). The second view is demandfollowing supported by studies such as Liang and Teng (2006), Ang and McKibbin (2007), Odhiambo (2008), Colombage (2009), Odhiambo (2010), Kar et al. (2011), Pradhan et al. (2013) which argues that growth leads to banking sector development. The third view is one of the bidirectional causalities. Accordingly, there is a mutual or two-way causal relationship between banking sector development and economic growth. Studies such as those of Ahmed and Ansari (1998), Craigwell et al. (2001) Dritsakis and Adamopoulos (2004), Wolde-Rufael (2009), Chow and Fung (2013), Pradhan et al. (2013), Pradhan et al. (2014). 
Consequently, the current verdict on the relationship between banking sector development and economic growth and their causality has remained inconclusive. However, the discussion focuses on measures of banking sector development, which must move literature because most authors only analyze an approach that from the outputs and the same database published by the International Monetary Fund (IMF) and the World Bank. Accordingly, it is logical to find almost the same results. In addition, what might be an adequate banking system at one time or in one social, institutional and economic environment may be outright detrimental at another time or in other environments. In other words, there may be various structural shifts or breaks which further complicate identification of causal relationships.

Conversely to the traditional analysis of the finance-growth relationship, Graff (2001, 2002, and 2005) proposed an alternative approach to the traditional work, to assess the level of banking sector development, for the banking sector Inputs and its impact on economic performance. This new approach is based on Graff resources available for development of the banking system and can be summarized in three indicators: the share of manpower employed in the banking system, the banking system's share in gross domestic product (GDP) and the number of banks and branches per capita.

The economic historians are able to give convincing examples for all possibilities of all causality outlined above. There is, obviously, the need for further research. The paper contributes to the existing literature in four important aspects. First to the best of our knowledge, this is the first study that uses a tow indices of banking sector development refer to the Inputs and Outputs of the banking system. Second, The sample adopted for the dataset is wider than other contributions based on the panel approach and includes forty developing countries $^{1}$ from 1970-2012. Third, this study is the first researches used a bootstrap panel Granger causality test to investigate the causal relationship between banking sector development and economic growth. This allows testing for Granger causality on each individual panel member separately by taking into account the possible contemporaneous correlation across countries (Kònya, 2006; Chang et al. 2013; Menyah et al. 2014). Fourth, we take into consideration cross sectional dependence and country-specific heterogeneity across the forty countries. We hope that this study can bridge the gap in the current literature between banking sector development and economic growth.

The remainder of this paper is structured as follows: Section 2 describes the data and the construction of banking sector development indices used in the empirical analysis. Section 3 presents a brief discussion of the cross-sectional dependence test, the slope heterogeneity test and the bootstrap panel Granger causality test proposed by Kónya (2006). Results are discussed in Section 4. Finally, Section 5 presents the conclusions that we draw from this research.

\footnotetext{
${ }^{1}$ Developing countries are defined according to their Gross National Income (GNI) per capita per year. Countries with a GNI of US\$ 11,905 and less are defined as developing (specified by the World Bank, 2013).
} 


\section{Data and the construction of banking sector development indices}

We use annual data over the period 1970 to 2012 for forty developing countries. Economic growth is proxied by real GDP per capita. The sample excluding countries that are very small (less than one million), countries with centrally planned economies ${ }^{2}$ during the period 1970 2012, countries where oil exports constituted over $20 \%$ of GDP in 1995, and countries with civil wars claiming a death toll exceeding $2.5 \%$ of the total population during 1970-2012.The exclusion of these countries in the sample is justified by the fact that it is unreasonable to run regressions across countries that are fundamentally different from the usual conditions (Harberger, 1998).

One of the most important issues in assessing the relationship between banking sector development and economic growth is how to obtain a satisfactory empirical measure of banking sector development. An increase in financial instruments and the foundation of these instruments more commonly available in a country is defined as banking sector development. Various measures have been used in the literature to proxy for the "level of banking sector development". The existing literature for the measurement of banking sector development (BSD) comprises two different categories. The first category is traditionally based on Outputs on the banking sector. Gregorio and Guidotti (1995), Levine and Zervos (1998), Rousseau and Wachtel (1998), Beck and Levine (2004), Liang and Teng (2006), Naceur and Ghazouani (2007), Abu-Bader and Abu-Qarn (2008), Gries et al. (2009), Banos et al. (2011), Pradhan et al. (2013) discuss different indicators Outputs of banking sector development capturing the size, activity and efficiency of the banking sector. The second category based on Inputs on the banking sector. Graff (2001, 2002 and 2005) a proposing new set of proxies for banking sector development based on the Inputs of the banking system. The construction of the new variable for banking sector development is motivated by the interest in obtaining a reasonably reliable and comparable quantification of the proportion of societal resources devoted to the banking system.

Ang and McKibbin (2007) explains that there is no broad consensus among economists as to which of the proxies of financial development is the best measurement and more so these proxies are highly correlated. Therefore, it is really difficult to have a single measure of financial development that could highlight all the aspects of the financial system (Huang, 2011). The use of principal component analysis (PCA) for the aggregate index of financial development is gaining popularity in growth finance literature to construct a summary index of financial development and other dimensions of financial systems (Ang and McKibbin, 2007; Gries et al. 2009; Huang, 2011).

We use the composite indicators for both Outputs and Inputs ${ }^{3}$ by using the banking sector indicators above and through PCA. The first component of our index of Outputs banking sector development is Broad money supply: Broad money supply, expressed as a percentage of GDP, is the sum of currency outside banks; demand and term deposits, including foreign currency deposits of resident sectors (other than the central bank); certificates of deposit and commercial paper. The second component is Domestic credit provided by the banking sector: It includes all credit to various sectors on a gross basis, with the exception of credit to the central government. It is expressed as a percentage of gross domestic products. Finally, the third component of our aggregate summary index is Domestic credit to the private sector: This credit, expressed as a percentage of GDP, refers to financial

\footnotetext{
${ }^{2}$ Centrally planned economies were characterized by the dominance of large enterprises, while SMEs hardly existed.

${ }^{3}$ For details and sources, see the appendix.
} 
resources provided to the private sector, such as through loans, purchases of non-equity securities, trade credits and other accounts receivable that establish a claim for payment. The data are abstracted and transformed from World Development Indicators, published by the World Bank and we use the natural log of these variables in our estimation.

Based on Graff (2001, 2002 and 2005) studies, we employ three indicators to construct the second Input index of banking sector development are discussed below.

The banking system's share in GDP, that is to say, the factor incomes generated in the banking sector, is probably the best indicator. More specifically, the share of the banking system in GDP consists of wages and the labor markets are characterized by the optimality of wages fixed by the market. This is based on equality between wages and marginal productivity of labor. The sector's share is valued at conditions that are very close to what most economists consider appropriate. Following this line of reasoning, the only flaw is to point to the observation that in the real world factor markets are frequently far from resulting in market clearing prices, so that some reservation is called for.

The second indicator is the number of banks and branches per capita, which gives an idea about the degree to which a country's population has access to financial services. Obviously, the validity of this indicator is weakened by differences in the dispersion of a country's population over its territory. In addition to this, technical progress and financial innovations, such as, telephone and Internet banking have made the accessibility of a bank office obsolete for many financial interactions and services. Thus, although this measure indicates a decline in banking sector development in most developed countries in recent years is the result of innovations in the banking sector and thus a sign of progress rather than a decline.

Finally, we refer to the share of manpower employed in the banking system. This measure is questionable because it ignores the productivity levels of those working in the banking system. To address this problem, we suggest a weighting of raw numbers of employees with an internationally comparable labour productivity proxy, mean years of schooling of the population aged 25-65 years (Barro and Lee, 1996), which results in an indicator for 'effective' rather than 'raw' labour. For a first picture, this correction, albeit imperfect, should, at least to some degree, improve the validity of our manpower indicator.

Table 1 presents the results of principal component analysis with the three Outputs and three Inputs measures of BSD listed above.

The eigenvalue associated with the first component is significantly larger than one of the two sets of BSD indicators (Outputs and Inputs). The first principal component explains approximately $89.2 \%$ and $83 \%$ of the standardized variance (a total of $70 \%$ of variance explained is generally considered acceptable); the second principal component explains another $8.5 \%$ and $13 \%$, and the last principal component accounts for only $1.3 \%$ and $3.9 \%$ of the variation (respectively for Outputs and Inputs banking sector development indicators). Clearly, the first principal component is the best two indices of BSD in this case. Below, we denote these summary indices of BSD as OBS for Outputs and IBS for Inputs. 
Table 1 Banking sector development indices analysis

Outputs Banking Sector (OBS) Development Indicators

\begin{tabular}{lcccc}
\hline Component & Eigenvalues & Difference & Proportion & Cumulative \\
\hline Comp 1 & 2.677 & 2.392 & 0.892 & 0.892 \\
Comp 2 & 0.285 & 0.247 & 0.095 & 0.987 \\
Comp 3 & 0.038 & & 0.013 & 1.000 \\
\hline \multicolumn{5}{c}{} \\
\hline Component & Eigenvalues & Difference & Proportion & Cumulative \\
\hline Comp 1 & 2.489 & 2,096 & 0.830 & 0.830 \\
Comp 2 & 0.393 & 0.275 & 0.131 & 0.961 \\
Comp 3 & 0.118 & & 0.039 & 1.000 \\
\hline
\end{tabular}

\section{Econometric Methodology}

The empirical analysis in this paper is carried out in two steps. First, as a prerequisite to our Granger causality tests, we carry out tests for cross-section dependence and slope homogeneity. In the second step, based on the results from preliminary analysis, we apply a panel causality test that takes into consideration the issues of cross-section dependence and slope homogeneity (Kònya, 2006). A brief account of the econometric models used is presented below.

Recent advances in panel causality analysis have brought to the fore two basic econometric issues that cannot be ignored in under taking panel Granger causality tests. The first concerns the issue of cross-dependence and the second concerns the issue of heterogeneity across countries. The recent world economic situation has shown that turbulence in a country can easily be transmitted to other countries through international trade and economic and financial integration (Nazilioglu et al. 2011). As pointed out by Pesaran (2006) ignoring cross-section dependency leads to substantial bias and size distortions implying that testing for the cross-section dependence is a crucial step in a panel data analysis (Nazilioglu et al. 2011; Chu and Chang, 2012; Boubtane et al. 2013; Chang et al. 2013).

\subsection{Cross-section dependence tests}

The first step in analyzing panel data Granger causality is testing for cross-sectional dependence. Following Kónya (2006); Kar et al. (2011); Boubtane et al. (2013); Chang et al. (2013) we employ four different cross-sectional dependence test statistics. The first is the Lagrange Multiplier (LM) test developed by Breusch and Pagan (1980) which requires the estimation of the following panel data model:

$$
\ln y_{i, t}=\alpha_{i}+\beta_{i} \ln x_{i, t}+\varepsilon_{i, t} \quad \text { for } \quad i=1,2, \ldots \ldots \ldots \ldots \ldots, N ; t=1,2, \ldots \ldots \ldots \ldots \ldots \ldots \ldots, T
$$


In Eq. (1), $y_{i, t}$ is real GDP per capita, $i$ is the cross-sectional dimension, $t$ is the time dimension, $x_{i, t}$ Is $k \times 1$ vector of explanatory variables (OBS or IBS), $\alpha_{i}$ and $\beta_{i}$ are the individual intercepts and slope coefficients that are allowed to differ across states. The null hypothesis of no-cross sectional dependence, $H_{0}: \operatorname{Cov}\left(\varepsilon_{i, t}, \varepsilon_{j, t}\right)=0$, for all $t$ and $i \neq j$ is tested against the alternative hypothesis of cross-sectional dependence, $H_{0}: \operatorname{Cov}\left(\varepsilon_{i, t}, \varepsilon_{j, t}\right) \neq 0$ , for at least one pair of $i \neq j$. For testing the null hypothesis, Breusch and Pagan (1980) developed the following LM test:

$$
L M=T \sum_{i=1}^{N-1} \sum_{j=i+1}^{N} \hat{\rho}_{i j}^{2}
$$

In Eq. (2) $\hat{\rho}_{i j}^{2}$ is the sample estimate of the pair-wise correlation of the residuals from individual ordinary least squares (OLS) estimation of the Eq. (1) for each $i$. Under the null hypothesis of no cross-sectional dependency with a fixed $N$ (number of cross-sections) and time period $T \rightarrow \infty$, the statistic has a chi-square asymptotic distribution with $N(N-1) / 2$ degrees of freedom (Greene, 2003, p.350). It is important to note that the $L M$ test is applicable with $N$ relatively small and $T$ sufficiently large. To overcome this problem, Pesaran (2004) proposed the following $L M$ statistic for the cross-section dependency test (the so-called $C D_{L M}$ test)

$$
C D_{L M}=\sqrt{\frac{1}{N(N-1)}} \sum_{i=1}^{N-1} \sum_{j=i+1}^{N}\left(T \hat{\rho}_{i j}^{2}-1\right)
$$

Under the null hypothesis of no cross-sectional dependence with $T \rightarrow \infty$ and, this test statistic has the standard normal distribution. Though $C D_{L M}$ is applicable even for $N$ and $T$ large, it is likely to exhibit substantial size distortions when $N$ is large relative to $T$. The shortcomings of the $L M$ and the $C D_{L M}$ tests clearly show a need for a cross-sectional dependency test that can be applied with large $N$ and small $T$. In that respect, Pesaran (2004) proposed the following test for cross-sectional dependence $C D$ :

$$
C D=\sqrt{\frac{2 T}{N(N-1)}} \sum_{i=1}^{N-1} \sum_{j=i+1}^{N} \hat{\rho}_{i j}
$$

However, the $C D$ test will lack power in certain situations where the population average pair-wise correlations are zero, but the underlying individual population pair-wise correlations are non-zero (Pesaran et al. 2008, p. 106). Furthermore, when the mean of the factor loadings is zero in the cross-sectional dimension, the $C D$ test can not reject the null hypothesis in stationary dynamic (Sarafidis and Robertson, 2009). To address these problems, Pesaran et al. (2008) proposes a bias-adjusted test which is a modified version of the $L M$ test that uses the exact mean and variance of the $L M$ statistic. The bias-adjusted $L M$ test is as follows:

$$
L M_{a d j}=\sqrt{\frac{2 T}{N(N-1)}} \sum_{i=1}^{N-1} \sum_{j=i+1}^{N} \frac{(T-K) \hat{\rho}_{i j}^{2}-\mu_{T i j}}{\sqrt{v_{T i j}^{2}}}
$$

Where $\mu_{T i j}$ and $v_{T i j}^{2}$ are respectively the exact mean and variance of $(T-k) \rho_{i j}^{2}$ provided in Pesaran et al. (2008, p.108). Pesaran et al. (2008) showed that under the null hypothesis of no cross-sectional dependence with $T \rightarrow \infty$ first followed by $N \rightarrow \infty$, the statistics $L M_{a d j}$ follow an asymptotic standard normal distribution. 


\subsection{Slope homogeneity tests}

Another important point in the bootstrap panel causality approach is testing for cross-country heterogeneity. It does not allow us to capture heterogeneity due to country specific characteristics, if the slope homogeneity is assumed without any empirical evidences (Breitung, 2005; Menyah et al. 2014). In addition, Granger (2003) stated that the causality from one variable to another variable by imposing the joint restriction for whole panel is a strong null hypothesis. The null hypothesis of slope homogeneity and the alternative hypothesis of heterogeneity can be described as follows: $H_{0}: \beta_{i}=\beta$, for all $i, H_{1}: \beta_{i} \neq \beta_{j}$, for a nonzero fraction of pair-wise slopes for $i=j$. To test for the null hypothesis, the customary approach is to follow the Wald principle. Accordingly, the test of slope homogeneity is $\beta_{i}=\ldots \ldots . . .=\beta_{N}$, where the Wald statistic is asymptotically distributed chisquared with N-1 degrees of freedom (Mark et al. 2005). Fisher's exact test (F) is valid for cases where the cross section dimension $(N)$ is relatively small and the time dimension $(T)$ of panel is large; the explanatory variables are strictly exogenous; and the error variances are homoscedastic. In order to relax the assumption of homoscedasticity in the $\mathbf{F}$ test, Swamy (1970) developed the slope homogeneity test to detect cross-sectional heteroscedasticity (Pesaran and Yamagata, 2008). However, Wald and Swamy tests are applicable for panel data models where $N$ is small relative to $T$. Pesaran and Yamagata (2008) proposed a standardized version of Swamy's test (the so-called $\tilde{\Delta}$ test) for testing slope homogeneity in large panels.

The $\tilde{\Delta}$ test is valid as $(N, T) \rightarrow \infty$ without any restrictions on the relative expansion rates of $N$ and $T$ when the error terms are normally distributed. In the $\tilde{\Delta}$ test approach, the first step is to compute the following modified version of the Swamy's test:

$$
\tilde{S}=\sum_{i=1}^{N}\left(\hat{\beta}_{i}-\tilde{\beta}_{W F E}\right)^{\prime} \frac{x^{\prime} M_{T}-x_{i}}{\tilde{\sigma}_{i}^{2}}\left(\hat{\beta}_{i}-\tilde{\beta}_{W F E}\right)
$$

In Eq. (6), $\hat{\beta}_{i}$ is the estimator from the pooled OLS and $\tilde{\beta}_{W F E}$ is the estimator from the weighted fixed effect pooled estimation of the regression model of Eq. (1); $M_{T}$ is an identity matrix, and $\tilde{\sigma}_{i}^{2}$ is the estimator of $\sigma_{i}^{2}$. Pesaran and Yamagata (2008) then developed the following standardized dispersion statistic:

$$
\tilde{\Delta}=\sqrt{N}\left(\frac{N^{-1} \tilde{S}-K}{\sqrt{2 K}}\right)
$$


Under the null hypothesis with the condition of $(N, T) \rightarrow \infty$, so long as $\sqrt{N} / T \rightarrow \infty$ and the error terms are normally distributed, the $\tilde{\Delta}$ test has an asymptotic standard normal distribution. The small sample properties of the $\tilde{\Delta}$ test can be improved under normally distributed errors by using the following bias-adjusted version:

$$
\tilde{\Delta}_{a d j}=\sqrt{N}\left(\frac{N^{-1} \tilde{S}-E\left(\tilde{Z}_{i, t}\right)}{\sqrt{\operatorname{var}\left(\tilde{Z}_{i, t}\right)}}\right)
$$

Where the mean is $E\left(\tilde{Z}_{i, t}\right)=k$ and the variance is $\operatorname{var}(\tilde{Z})=2 k \frac{T-k-1}{T}+1^{4}$.

\subsection{Panel Granger non-causality test}

The approach proposed by Kònya (2006) was recently used in the analysis of finance-growth nexus. Kar et al. (2011) examined the linkages between financial development and economic growth in the MENA countries, Hsueh et al. (2013) analyzed the connections between economic growth and financial development in Asian countries. Menyah et al. (2014) identify Granger causality between financial development, trade openness and economic growth in African countries. This study is the first that uses a bootstrap panel Granger causality test to investigate the causal relationship between banking sector development and economic growth in developing countries. The tools used for bootstrap panel causality tests are presented below.

The panel causality approach by Kónya (2006) that examine the relation-ship between $\mathbf{Y}$ and BSD can be studied using the following bivariate finite-order vector autoregressive (VAR) model:

$$
\left\{\begin{array}{l}
y_{i, t}=\alpha_{1, i}+\sum_{s=1}^{l y_{1}} \beta_{1, i, s} y_{i, t-s}+\sum_{s=1}^{l B S D_{1}} \gamma_{1, i, s} B S D_{i, t-s}+\varepsilon_{1, i, t} \\
B S D_{i, t}=\alpha_{2, i}+\sum_{s=1}^{l y_{2}} \beta_{2, i, s} y_{i, t-s}+\sum_{s=1}^{l B S D_{2}} \gamma_{2, i, s} B S D_{i, t-s}+\varepsilon_{2, i, t}
\end{array}\right.
$$

In the equation systems (9), $\mathbf{y}$ denotes real GDP per capita, BSD is the banking sector development indices (OBS or IBS) obtained through principal component analysis, index $i$ refers to the country $(i=1, \ldots \ldots . N), t$ to the time period $(t=1, \ldots \ldots . T), s$ the lag, $l y_{1}, l B S D_{1}$, $l y_{2}$ and $l B S D_{2}$ indicate the lag lengths. The error terms, $\varepsilon_{1, i, t}$ and $\varepsilon_{2, i, t}$ are supposed to be white-noises (i.e. they have zero means, constant variances and are individually serially uncorrelated) that may be correlated with each other for a given country, but not across countries 5 .

Since for a given country the two equations in (9) contain the same pre-determined, i.e. lagged exogenous and endogenous variables, the OLS estimators of the parameters are consistent and asymptotically efficient. This suggests that the $2 \mathrm{~N}$ equations in the system can be estimated one-by-one, in any preferred order. Then, instead of $N$ VAR systems in (9), we can consider the following two sets of equations:

\footnotetext{
${ }^{4}$ See Chang, et al. (2013).

${ }^{5} \varepsilon_{1, \mathrm{i}, \mathrm{t}}$ and $\varepsilon_{2, \mathrm{i}, \mathrm{t}}$ are correlated when there is feedback between BSD and Y, i.e. in the non-reduced form of (1), called structural VAR, $\mathrm{y}_{\mathrm{t}}$ depends on $\mathrm{BSD}_{\mathrm{t}}$ and/or $\mathrm{BSD}_{\mathrm{t}}$ depends on $\mathrm{y}_{\mathrm{t}}$. For a proof see Enders (2004, p. 266).
} 


$$
\left\{\begin{array}{l}
y_{1, t}=\alpha_{1,1}+\sum_{s=1}^{l y_{1}} \beta_{1,1, s} y_{1, t-s}+\sum_{s=1}^{l B S D_{1}} \gamma_{1,1, s} B S D_{1, t-s}+\varepsilon_{1,1, t} \\
y_{2, t}=\alpha_{1,2}+\sum_{s=1}^{l y_{1}} \beta_{1,2, s} y_{2, t-s}+\sum_{s=1}^{l B S D_{1}} \gamma_{1,2, s} B S D_{2, t-s}+\varepsilon_{1,2, t} \\
\cdot \\
y_{N, t}=\alpha_{1, N}+\sum_{s=1}^{l y_{1}} \beta_{1, N, s} y_{N, t-s}+\sum_{s=1}^{l B S D_{1}} \gamma_{1, N, s} B S D_{N, t-s}+\varepsilon_{1, N, t}
\end{array}\right.
$$

and

$$
\left\{\begin{array}{l}
B S D_{1, t}=\alpha_{2,1}+\sum_{s=1}^{l y_{2}} \beta_{2,1, s} y_{1, t-s}+\sum_{s=1}^{l B S D_{2}} \gamma_{2,1, s} B S D_{1, t-s}+\varepsilon_{2,1, t} \\
B S D_{2, t}=\alpha_{2,2}+\sum_{s=1}^{l y_{2}} \beta_{2,2, s} y_{2, t-s}+\sum_{s=1}^{l B S D_{2}} \gamma_{2,2, s} B S D_{2, t-s}+\varepsilon_{2,2, t} \\
\cdot \\
B S D_{N, t}=\alpha_{2, N}+\sum_{s=1}^{l y_{2}} \beta_{2, N, s} y_{N, t-s}+\sum_{s=1}^{l B S D_{2}} \gamma_{2, N, s} B S D_{N, t-s}+\varepsilon_{2, N, t}
\end{array}\right.
$$

In this system, each equation has the different predetermined variables. The only possible link among individual regressions is contemporaneous correlation within the systems. Therefore, system (10) and (11) must be estimated by Seemingly Unrelated Regression (SUR) procedure to take into account contemporaneous correlation within the systems (in presence of contemporaneous correlation the SUR estimator is more efficient than the OLS estimator). Following Kónya (2006), we use country specific bootstrap Wald critical values to implement Granger causality. This procedure ${ }^{6}$ has several advantages. Firstly, it does not assume that the panel is homogeneous, so it is possible to test for Granger-causality on each individual panel member separately. However, since contemporaneous correlation is allowed across countries, it makes possible to exploit the extra information provided by the panel data setting. Therefore, country specific bootstrap critical values are generated. Secondly, this approach does not require pretesting for unit roots and cointegration, though it still requires the specification of the lag structure. This is an important feature since the unitroot and cointegration tests in general suffer from low power, and different tests often lead to contradictory outcomes. Thirdly, this panel Granger causality approach allows the researcher to detect for how many and for which members of the panel there exists one-way Grangercausality, two-way Granger-causality or no Granger-causality.

In the equation systems (10) and (11), for each country one of four possible bootstrap panel causality hypotheses can be derived. (i) there is one-way Granger causality from BSD to $y$ if not all $\gamma_{1, i}$ are zero, but all $\beta_{2, j}$ are zero, (ii) there is one-way Granger causality running

\footnotetext{
${ }^{6}$ For the details and exposition of the estimation and testing procedures, see Kónya (2006), Kar et al. (2011).
} 
from $y$ to BSD if all $\gamma_{1, i}$ are zero, but not all $\beta_{2, j}$ are zero, (iii) there is two-way Granger causality between BSD and $y$ if neither $\gamma_{1, i}$ nor $\beta_{2, j}$ are zero, and finally (iv) there is no Granger causality between BSD and $y$ if all $\gamma_{1, i}$ and $\beta_{2, j}$ are zero (Chang et al. 2013).

\section{Results and Discussions}

As outlined earlier, testing for both cross-sectional dependence and slope homogeneity in the bootstrap panel causality analysis is crucial for selecting the appropriate estimator and for imposing restrictions on causality. Because the countries examined in this work are highly integrated with regard to their economies, it is necessary to consider cross-sectional dependency and slope heterogeneity, and the results for this are shown in Table 2. First, we use four statistics, $L M$ (Breusch and Pagan, 1980), $C D_{L M}$ and $C D$ (Pesaran, 2004) and $L M_{a d j}$ (Pesaran et al. 2008). It is clear that the null hypothesis of no cross-sectional dependence across the countries is strongly rejected at the conventional significance levels; this implies that the SUR method is more appropriate than the country-by-country OLS estimation. This finding implies that uncertainty shocks occurred in a particular country is transmitted to other countries, due to a high degree of globalization, market integration, and close economic linkages in the countries.

Table 2 also reports the results from the slope homogeneity test developed by Swamy (1970) and Pesaran and Yamagata (2008). The statistics are taken from Swamy (1970), $\widetilde{\Delta}$ and $\tilde{\Delta}_{a d j}$ (both taken from Pesaran and Yamagata (2008)), and the null hypothesis is that after conducting the regression analysis of Eq.(1) the slope coefficients of the explanatory variables are the same among all each countries surveyed. The results strongly reject the null hypothesis of homogeneous slope, and support the alternative hypothesis that heterogeneity exists among countries, and thus that individual countries are affected by their own specific characteristics. The rejection of the homogeneous slope hypothesis means that inaccurate outcomes will be obtained if we impose the constraint of slope homogeneity. In this scheme of things, the direction of causal linkages between banking sector development and economic growth in developing countries is rather heterogonous, or in other words, the directional causal linkages between the variables of interest may differ across these countries (Chang et al. 2013).

Table 2 Cross-sectional dependence and homogeneous tests

\begin{tabular}{lllc}
\hline Study & Test & OBS & IBS \\
& Stat & & \\
\hline Breush and Pangan (1980) & $L M$ & $51.346^{* * *}$ & $40.334^{* *}$ \\
Pesaran (2004) & $C D_{L M}$ & $5.008^{* * * *}$ & $4.445^{* * *}$ \\
& $C D$ & $3.412^{* * * *}$ & $3.224^{* * *}$ \\
Pesaran et al. (2008) & $L M_{a d j}$ & $18.115^{* * *}$ & $20.058^{* * *}$ \\
Swamy (1970) & $\tilde{S}$ & $30.694^{* * *}$ & $23.426^{* * *}$ \\
Pesaran and Yamagata (2008) & $\tilde{\Delta}$ & $5.013^{* * * *}$ & $3.513^{* * *}$ \\
& $\tilde{\Delta}_{a d j}$ & $6.005^{* * * *}$ & $4.319^{* * * *}$ \\
\hline
\end{tabular}

Note: $* * *$ and $* *$ indicate significance at the 0.01 and 0.05 levels, respectively. 
Having established the existence of cross-sectional dependency and heterogeneity across countries we apply the bootstrap panel causality approach developed by Kónya (2006). However, before proceeding to estimation, optimal lag lengths must be determined. Since the results from the causality test may be sensitive to the lag structure, determining the optimal lag length(s) is crucial for the robustness of empirical findings (Chang and Hsieh, 2012).

Again following Kónya (2006) we estimate the system for each possible pair of $l y_{1}, l B S D_{1}$, $l y_{2}$ and $l B S D_{2}$ respectively by assuming lags ranging from 1 to 4 and then choose the combinations which minimize the Akaike Information Criterion $\left(A I C_{k}\right)$ (Kónya, 2006) and Schwartz Information Criterion $\left(S C_{k}\right)^{7}$ defined as follows:

$$
A I C_{k}=\ln |W|+\frac{2 N^{2} q}{T} \quad \text { and } \quad S C_{k}=\ln |W|+\frac{N^{2} q}{T} \ln (T)
$$

Where $W$ stands for estimated residual covariance matrix, $N$ is the number of equations, $q$ is the number of coefficients per equation, $T$ is the sample size, all in system $k=1,2$. Occasionally, these two criteria select different lag lengths.

The existence of cross-sectional dependence and sectional dependence and heterogeneity across states reject the null hypothesis of slope homogeneity for each of countries, it is justified to use the Bootstrap Panel Granger Causality method in Kónya (2006). For each system of equations the number of lags was chosen according to the $A I C_{k}$ and $S C_{k}$ criterion. Additionally, specifications incorporating deterministic trend were taken into account. The results from the bootstrap panel Granger causality ${ }^{8}$ analysis are reported in Tables 3 and 4 . We discuss our empirical findings for each country and both the banking sector development Indices (Outputs and Inputs) in the following sections.

In Table 3 we show the results from panel causality analysis between OBS and economic growth. For Benin, Brazil, Costa Rica, Iran, Jordan, Malawi, South Africa, Tanzania and Thailand there was a unidirectional causality running from OBS to economic growth, supporting the supply-leading hypothesis. In contrast, in the case of El Salvador, India, Jamaica, Mexico, Panama, Sri Lanka and Tunisia there was a unidirectional causality running from economic growth to OBS, supporting the demand-following hypothesis. In the case of Argentina, Malaysia and Morocco we found support for the feedback hypothesis where there was a bi-directional causality running between OBS and economic growth. In the remaining twenty one countries or for more than half of the sample there was no causality running in any direction between OBS and economic growth evidence consistent with the neutrality hypothesis.

\footnotetext{
${ }^{7}$ In order to save space, results from the lag selection procedure are not shown in the paper but are available upon reader's request.

${ }^{8}$ The TSP routine written by László Kónya was used to obtain the results for the panel Granger causality test. We are grateful to László Kónya for sharing his codes.
} 
Table 3 Results for panel causality (BSD indicator)

\begin{tabular}{|c|c|c|c|c|c|c|c|c|}
\hline \multirow[t]{3}{*}{ Countries } & \multicolumn{4}{|c|}{$H_{0}$ : OBS does not Granger cause GDP } & \multicolumn{4}{|c|}{$H_{0}:$ GDP does not Granger cause OBS } \\
\hline & \multirow{2}{*}{$\begin{array}{l}\text { Wald } \\
\text { statistics }\end{array}$} & \multicolumn{3}{|c|}{ Bootstrap critical value } & \multirow{2}{*}{$\begin{array}{l}\text { Wald } \\
\text { statistics }\end{array}$} & \multicolumn{3}{|c|}{ Bootstrap critical value } \\
\hline & & $10 \%$ & $5 \%$ & $1 \%$ & & $10 \%$ & $5 \%$ & $1 \%$ \\
\hline Argentina & $12.905 * * *$ & 10.761 & 15.654 & 31.971 & $59.969 *$ & 9.782 & 14.264 & 26.378 \\
\hline Benin & $11.005 * * *$ & 10.321 & 15.152 & 30.125 & 7.879 & 10.442 & 15.123 & 26.052 \\
\hline Botswana & 1.995 & 9.308 & 13.743 & 26.632 & 11.523 & 13.743 & 19.531 & 34.633 \\
\hline Brazil & $26.748 * *$ & 13.637 & 23.411 & 75.847 & 0.632 & 7.746 & 10.745 & 19.998 \\
\hline Burkina Faso & 9.792 & 13.012 & 18.114 & 31.459 & 0.014 & 12.946 & 18.005 & 32.003 \\
\hline Cameroon & 5.531 & 12.640 & 18.751 & 34.309 & 3.525 & 16.082 & 23.749 & 43.531 \\
\hline Central Afr Rep & 0.125 & 8.991 & 13.072 & 23.550 & 0.909 & 9.073 & 13.316 & 24.096 \\
\hline Colombia & 7.413 & 11.414 & 16.839 & 33.633 & 0.744 & 10.580 & 13.518 & 25.081 \\
\hline Costa Rica & $11.324 * * *$ & 10.597 & 15.641 & 30.545 & 7.872 & 10.638 & 15.526 & 26.401 \\
\hline Dominican Rep & 11.410 & 11.736 & 16.851 & 29.745 & 5.005 & 14.409 & 20.521 & 38.417 \\
\hline Ecuador & 0.521 & 10.483 & 15.524 & 31.183 & 5.408 & 17.978 & 26.069 & 44.739 \\
\hline Egypt & 2.187 & 10.415 & 15.524 & 31.083 & 2.954 & 10.423 & 15.290 & 27.519 \\
\hline El Salvador & 4.774 & 16.001 & 10.165 & 32.822 & 47.801* & 11.010 & 15.635 & 28.611 \\
\hline Guatemala & 4.631 & 14.632 & 22.636 & 51.523 & 5.206 & 7.317 & 10.958 & 20.252 \\
\hline Haïti & 0.295 & 8.103 & 11.927 & 20.727 & 0.003 & 7.805 & 11.893 & 22.114 \\
\hline India & 4.874 & 6.903 & 9.798 & 18.884 & $9.713 * *$ & 5.121 & 7.201 & 11.097 \\
\hline Iran & $11.281 * *$ & 9.619 & 14.173 & 25.952 & 1.391 & 11.623 & 16.954 & 30.902 \\
\hline Jamaica & 0.967 & 10.086 & 15.319 & 28.271 & $31.504 * *$ & 16.837 & 23.968 & 45.295 \\
\hline Jordan & $27.636 *$ & 8.962 & 13.302 & 23.979 & 5.305 & 13.967 & 19.855 & 35.971 \\
\hline Kenya & 0.063 & 8.187 & 11.702 & 20.835 & 0.276 & 9.651 & 14.397 & 29.802 \\
\hline Liberia & 0.007 & 10.908 & 15.802 & 27.072 & 3.673 & 9.941 & 14.179 & 25.413 \\
\hline Malawi & $10.084 *$ & 9.463 & 13.603 & 24.901 & 1.047 & 10.155 & 14.679 & 26.267 \\
\hline Malaysia & $13.295 * * *$ & 10.641 & 15.534 & 31.760 & $61.569 *$ & 9.452 & 13.874 & 26.319 \\
\hline Mali & 4.404 & 11.460 & 16.166 & 27.495 & 1.528 & 10.197 & 15.232 & 26.562 \\
\hline Mexico & 2.635 & 11.016 & 16.004 & 31.526 & $12.416 * * *$ & 9.303 & 13.286 & 25.295 \\
\hline Morocco & $13.607 * * *$ & 12.076 & 18.509 & 33.949 & $50.967 *$ & 15.298 & 21.943 & 38.830 \\
\hline Nepal & 4.926 & 11.371 & 16.197 & 28.863 & 0.174 & 8.962 & 12.603 & 22.605 \\
\hline Panama & 3.108 & 10.853 & 15.968 & 31.749 & $17.964 * * *$ & 15.744 & 22.975 & 42.197 \\
\hline Paraguay & 5.415 & 10.299 & 14.973 & 27.859 & 2.416 & 11.297 & 16.086 & 30.968 \\
\hline Peru & 0.986 & 10.439 & 17.212 & 39.988 & 0.765 & 10.879 & 15.992 & 30.028 \\
\hline Philippines & 3.511 & 9.973 & 14.524 & 27.959 & 1.513 & 16.201 & 23.202 & 42.429 \\
\hline Sierra Leone & 3.935 & 9.322 & 13.590 & 25.724 & 0.525 & 8.379 & 12.104 & 22.523 \\
\hline South Africa & $10.202 * * *$ & 10.294 & 15.405 & 31.196 & 0.845 & 9.417 & 13.518 & 23.599 \\
\hline Sri Lanka & 2.412 & 13.852 & 20.522 & 41.288 & $21.501 * *$ & 11.934 & 17.253 & 31.161 \\
\hline Tanzania & $10.037 *$ & 9.417 & 13.594 & 24.889 & 1.041 & 10.149 & 14.675 & 26.245 \\
\hline Thailand & $13.666^{* * * *}$ & 10.515 & 15.977 & 29.571 & 12.450 & 27.498 & 37.659 & 66.445 \\
\hline Togo & 2.769 & 10.032 & 14.374 & 25.466 & 0.043 & 10.548 & 15.102 & 27.732 \\
\hline Tunisia & 0.991 & 10.898 & 16.076 & 31.381 & $17.112 * * *$ & 15.783 & 22.405 & 39.545 \\
\hline Venezuela & 2.990 & 13.373 & 19.914 & 37.321 & 7.916 & 13.902 & 20.009 & 37.720 \\
\hline Zimbabwe & 0.987 & 8.008 & 11.638 & 23.008 & 0.275 & 9.854 & 14.179 & 25.067 \\
\hline
\end{tabular}

Note: $* * *, * * *$ indicate significance at the $0.01,0.05,0.1$ levels, respectively.

Table 4 presents the results for panel causality analysis between IBS and economic growth. 
Table 4 Results for panel causality (BSD indicator)

\begin{tabular}{|c|c|c|c|c|c|c|c|c|}
\hline \multirow[t]{3}{*}{ Countries } & \multicolumn{4}{|c|}{$H_{0}:$ IBS does not Granger cause GDP } & \multicolumn{4}{|c|}{$H_{0}:$ GDP does not Granger cause IBS } \\
\hline & \multirow{2}{*}{$\begin{array}{l}\text { Wald } \\
\text { statistics }\end{array}$} & \multicolumn{3}{|c|}{ Bootstrap critical value } & \multirow{2}{*}{$\begin{array}{l}\text { Wald } \\
\text { statistics }\end{array}$} & \multicolumn{3}{|c|}{ Bootstrap critical value } \\
\hline & & $10 \%$ & $5 \%$ & $1 \%$ & & $10 \%$ & $5 \%$ & $1 \%$ \\
\hline Argentina & $16.543 * *$ & 8.027 & 11.418 & 20.721 & 0.019 & 8.426 & 12.543 & 22.635 \\
\hline Benin & $7.725 * * *$ & 6.698 & 9.418 & 16.685 & 0.879 & 10.415 & 14.587 & 25.999 \\
\hline Botswana & $19.112 * * *$ & 7.045 & 10.154 & 18.135 & 0.035 & 9.558 & 13.342 & 24.748 \\
\hline Brazil & 0.954 & 6.787 & 9.992 & 16.871 & $10.216 * *$ & 6.529 & 9.671 & 17.371 \\
\hline Burkina Faso & 3.790 & 18.109 & 25.311 & 42.134 & 3.432 & 13.871 & 20.001 & 36.621 \\
\hline Cameroon & 2.651 & 9.098 & 13.453 & 25.613 & 0.647 & 14.041 & 21.109 & 36.887 \\
\hline Central Afr Rep & 2.691 & 9.006 & 13.246 & 24.013 & 0.107 & 14.013 & 20.752 & 38.212 \\
\hline Colombia & $11.987 *$ & 9.005 & 13.573 & 26.001 & 8.594 & 10.645 & 16.597 & 29.015 \\
\hline Costa Rica & 1.881 & 12.791 & 6.942 & 12.761 & 3.147 & 11.434 & 17.651 & 34.875 \\
\hline Dominican Rep & 4.161 & 15.037 & 22.152 & 40.037 & 0.601 & 8.998 & 12.402 & 24.312 \\
\hline Ecuador & 2.432 & 13.372 & 20.642 & 41.318 & $21.079 * *$ & 11.804 & 17.255 & 31.146 \\
\hline Egypt & 1.768 & 11.771 & 18.896 & 37.764 & $11.561 * * *$ & 14.013 & 26.632 & 40.667 \\
\hline El Salvador & 2.507 & 9.143 & 11.490 & 18.703 & $32.103 * * *$ & 9.231 & 8.681 & 15.541 \\
\hline Guatemala & 1.805 & 9.983 & 14.215 & 27.276 & 12.765 & 14.531 & 20.054 & 36.081 \\
\hline Haïti & 1.876 & 6.032 & 8.574 & 16.632 & 0.017 & 8.021 & 11.560 & 20.771 \\
\hline India & 0.695 & 8.168 & 12.014 & 28.209 & $14.975 * *$ & 10.543 & 14.124 & 22.544 \\
\hline Iran & 3.301 & 8.176 & 11.744 & 21.869 & 8.144 & 13.669 & 19.318 & 36.027 \\
\hline Jamaica & 2.312 & 13.676 & 20.565 & 41.318 & $21.102 * *$ & 11.897 & 17.376 & 31.301 \\
\hline Jordan & 3.401 & 10.756 & 15.634 & 30.101 & $15.296 * *$ & 10.298 & 14.545 & 26.672 \\
\hline Kenya & 0.874 & 14.605 & 20.759 & 38.069 & 0.307 & 16.466 & 23.523 & 41.187 \\
\hline Liberia & 1.537 & 12.973 & 20.620 & 39.765 & 7.006 & 9.380 & 14.378 & 26.911 \\
\hline Malawi & 3.246 & 5.901 & 8.724 & 16.014 & 0.012 & 7.597 & 11.461 & 20.196 \\
\hline Malaysia & $22.927 * * *$ & 7.279 & 10.564 & 19.154 & 0.051 & 10.213 & 14.698 & 25.792 \\
\hline Mali & 0.007 & 6.853 & 9.778 & 16.987 & 5.693 & 12.721 & 18.059 & 32.955 \\
\hline Mexico & 2.666 & 9.024 & 13.088 & 24.109 & 0.112 & 14.018 & 20.612 & 38.323 \\
\hline Morocco & $13.637 * * *$ & 12.096 & 18.529 & 33.969 & 49.997* & 15.402 & 21.965 & 38.865 \\
\hline Nepal & 3.544 & 9.598 & 14.471 & 28.113 & 0.932 & 22.117 & 30.012 & 51.969 \\
\hline Panama & 8.011*** & 6.957 & 9.767 & 17.320 & 0.911 & 10.972 & 15.144 & 26.752 \\
\hline Paraguay & 1.922 & 6.736 & 9.535 & 15.802 & 0.073 & 13.728 & 18.530 & 31.813 \\
\hline Peru & 0.013 & 8.269 & 12.199 & 22.751 & 0.091 & 12.163 & 17.044 & 29.720 \\
\hline Philippines & 4.033 & 7.794 & 11.153 & 20.799 & 8.925 & 13. 015 & 17.782 & 30.764 \\
\hline Sierra Leone & 1.221 & 7.182 & 10.513 & 18.321 & 0.371 & 11.927 & 16.989 & 29.555 \\
\hline South Africa & $13.295 * * *$ & 10.621 & 15.611 & 31.849 & 61.949* & 9.832 & 13.984 & 26.278 \\
\hline Sri Lanka & 27.606* & 8.942 & 13.292 & 23.959 & 5.295 & 13.877 & 19.835 & 35.941 \\
\hline Tanzania & 3.501 & 10.093 & 14.614 & 27.719 & 1.706 & 42.703 & 23.281 & 42.603 \\
\hline Thailand & 2.605 & 10.917 & 15.905 & 31.327 & $12.387 * * *$ & 9.271 & 13.001 & 25.208 \\
\hline Togo & $7.402 * * *$ & 6.297 & 9.015 & 16.343 & 0.865 & 10.391 & 14.564 & 25.981 \\
\hline Tunisia & 3.208 & 10.973 & 15.999 & 31.771 & $17.944 * * *$ & 15.724 & 22.955 & 42.167 \\
\hline Venezuela & 2.412 & 13.852 & 20.522 & 41.291 & $21.501 * *$ & 11.931 & 17.251 & 31.162 \\
\hline Zimbabwe & 2.182 & 11.059 & 17.294 & 35.040 & 12.151 & 14.271 & 22.022 & 41.221 \\
\hline
\end{tabular}

Note: $* * *, * *, *$ indicate significance at the $0.01,0.05,0.1$ levels, respectively.

Table 4 shows that there was a unidirectional causality running from IBS to economic growth in Argentina, Benin, Botswana, Colombia, Malaysia, Panama, Sri Lanka and Togo where the supply-leading hypothesis was supported. However, the opposite unidirectional causality running from economic growth to banking sector development was detected for Brazil, Ecuador, Egypt, El Salvador, India, Jamaica, Jordan, Thailand, Tunisia and Venezuela where the demand-following hypothesis was supported. In the case of Morocco and South 
Africa there was a bi-directional causality running between economic growth and banking sector development implying support for the "complementarity" hypothesis.

For the remaining twenty countries i.e. for half of the sample, the "neutrality" hypothesis is supported as there was no causality in any direction between banking sector development and economic growth. This is in sharp contrast to previous studies.

Some points are worth noting based on the results given above. Firstly, compared to the number of countries considered, Granger non causality in either direction can be rejected relatively rarely for OBS and IBS. As a result, the study provide no evidence to indicate that banking sector development is the most important determinant of economic growth in each country surveyed, and thus their banking sector development should be attributed to their own specific characteristics. Secondly, the results show that whether the causality from banking sector development to economic growth stands depends on the banking sector development indices (OBS or IBS) used for each country.

Furthermore, the results of this paper show that, whatever the banking sector development indices (Outputs or Inputs), the causal direction from banking sector development to economic growth is clearer only in Benin than in other countries. The findings support strong evidence on supply-leading hypothesis which implies that banking sector development induces economic growth. On the other hand, for three countries only (El Salvador, India and Tunisia) the findings support strong evidence on demand-following. Finally there is a bi-directional causality running between banking sector development and economic growth in Morocco implying support for the "complementarity" hypothesis.

\section{Summary and conclusion}

This paper revisited the Granger causal relationship between banking sector development and economic growth for forty countries using a bootstrap panel causality approach that allows for both cross-sectional dependency and for heterogeneity across countries for the period 19702012. We developed two banking sector development indices based on three indicators Outputs and three indicators Inputs of banking sector development using principal component analysis.

The empirical results show that the direction of causality between banking sector development and economic growth is sensitive to the choice of indices used Outputs or Inputs of banking sector development. The findings support evidence on the three demandfollowing, supply leading and complementarity hypotheses.

Some interesting conclusions emerge from this empirical study. First, none of the banking sector development indices causes economic growth in twenty three countries or for almost $57 \%$ of the sample (Burkina Faso, Cameroon, Central African Republic, Dominican Rep, Ecuador, Egypt, El Salvador, Guatemala, Haiti, India, Jamaica, Kenya, Liberia, Mali, Mexico, Nepal, Paraguay, Peru, Philippines, Sierra Leone, Tunisia, Venezuela and Zimbabwe). Second, as regards the causality from economic growth to banking sector development, the results show that banking sector development is not sensitive to economic growth in twenty three countries or for almost $57 \%$ of the sample (Benin, Botswana, Burkina Faso, Cameroon, Central African Republic, Colombia, Costa Rica, Dominican Rep, Guatemala, Haiti, Iran, Kenya, Liberia, Malawi, Mali, Nepal, Paraguay, Peru, Philippines, Sierra Leone, Tanzania, Togo and Zimbabwe). Third, sixteen countries or for almost $40 \%$ of the sample, the "neutrality" hypothesis is supported as there was no causality in any direction between banking sector development and economic growth, i.e. at least $62 \%$ of the sample there is a 
causal relationship between banking sector development and economic growth (twenty five countries: Argentina, Benin, Botswana, Brazil, Colombia, Costa Rica, Ecuador, Egypt, El Salvador, India, Iran, Jamaica, Jordan, Malawi, Malaysia, Mexico, Morocco, Panama, South Africa, Sri Lanka, Tanzania, Thailand, Togo, Tunisia and Venezuela).

\section{References}

ABU-BADER, S. and ABU-QARN, A. S. (2008). Financial development and economic growth: Empirical evidence from six MENA countries. Review of Development Economics, 12(4), pp. 803-817

AHMED, S. M. and ANSARI, M. I. (1998). Financial sector development and economic growth: The south-Asian experience. Journal of Asian Economics, 9(3), pp. 503-517

AL-MALKAWI, H.A.N., MARASHDEH H.A. and ABDULLAH, N. (2012). Financial development and economic growth in the UAE: Empirical assessment using ARDL approach to co-integration. International Journal of Economics and Finance, 4 (5), pp. 105-117

ANG, J. B. (2008b). What are the mechanisms linking financial development and economic growth in Malaysia? Economic Modelling, 25(1), pp. 38-53

ANG J.B. (2008a). A survey of recent developments in the literature of finance and growth. Journal of Economic Surveys, 22 (3), pp. 536-576

ANG, J.B. and MCKIBBIN, W.J. (2007). Financial liberalization, financial sector development and growth: evidence from Malaysia. Journal of Development Economics, 84 (1), pp. 215-233

ARCAND. J., BERKES, E. and PANIZZA, U. (2012). Too Much Finance? International Monetary Fund. Research Department 12/161

BAGEHOT, W. (1873). Lombard Street, Homewood, IL: Richard D. Irwin, 1962 edition BANOS, J. L., CROUZILLE, C. M., NYS, E. and SAUVIAT, A. (2011). Banking industry structure and economic activities: A regional approach for the Philippines. Philippines Management Review, 18(1), pp. 97-113

BARRO, R. and LEE, JW. (1996). International measures of schooling years and schooling quality. American Economic Review, Papers and Proceedings, 86, pp. 218-223

BECK, T. and LEVINE, R. (2004). Stock Markets, Banks, and Growth: Panel Evidence. Journal of Banking and Finance, 28(3), pp. 423-442

BECK, T., LEVINE, R. and LOAYZA, N. (2000). Finance and the sources of growth. Journal of Financial Economics, 58, pp. 261-300

BERTHELEMY, J. C. and VAROUDAKIS, A. (1996). Economic growth, convergence clubs, and the role of financial development. Oxford Economic Papers, 48(2), pp. 300-328

BLACKBURN, K. and HUNG, V. T. Y. (1998). A theory of growth, financial development and trade. Economica, 65(257), pp. 107-124

BOJANIC, A. N. (2012). The impact of financial development and trade on the economic growth of Bolivia. Journal of Applied Economics, 15(1), pp. 51-70

BOUBTANE, E., COULIBALY. D. and RAULT, C. (2013). Immigration, unemployment and GDP in the host country, Bootstrap panel Granger causality analysis on OECD countries. Economic Modelling, 33, pp. 261-269

BREITUNG, J. (2005). A Parametric Approach to the Estimation of Cointegration Vectors in Panel Data. Econometric Reviews, 24(2), pp. 151-174

BREUSCH, T. and PAGAN, A. (1980). The LM test and its Application to Model Specification in Econometrics. Review of Economic Studies, 47, pp. 239-254

CALDERON, C. and LIU, L. (2003). The direction of causality between financial development and economic growth. Journal of Development Economics, 72(1), pp. 321-334 
CHAIECHI, T. (2012). Financial development shocks and contemporaneous feedback effect on key macroeconomic indicators: A post Keynesian time series analysis. Economic Modelling, 29(2), pp. 487-501

CHANG, TY. and HSIEH, WK. (2012). Does Insurance Activity Promote Output? Further Evidence Based on Bootstrap Panel Granger Causality Test. Working paper Feng Chia University

CHANG, TY., SIMO-KENGNE, B.D. and GUPTA, R. (2013). The Causal Relationship between House Prices and Economic Growth in the Nine Provinces of South Africa: Evidence from Panel-Granger Causality Tests. Department of Economics Working Paper N²013/17. University of Pretoria

CHOW, W. W. and FUNG, M. K. (2013). Financial development and growth: A clustering and causality analysis. Journal of International Trade and Economic Development, 32 (3), pp. 430-453

CHU, H.P. and CHANG, T. (2012). Nuclear energy consumption, oil consumption and economic growth in G-6 countries, bootstrap panel causality test. Energy Policy, 48, pp. 762769

COLOMBAGE, S. R. N. (2009). Financial markets and economic performances: Empirical evidence from five industrialized countries. Research in International Business and Finance, 23(3), pp. 339-348

CRAIGWELL, R., DOWNES, D. and HOWARD, M. (2001). The finance-growth nexus: A multivariate VAR analysis of a small open economy. Savings and Development, 25(2), pp. 209-223

DEIDDA, L. and FATTOUH, B. (2002). Non-linearity between finance and growth. Economics Letters, 74(3), pp. 339-345

DRITSAKIS, N. and ADAMOPOULOS, A. (2004). Financial development and economic growth in Greece: An empirical investigation with Granger causality analysis. International Economic Journal, 18(4), pp. 547-559

ENDERS, W. (2004). Applied Econometric Time Series Analysis. 2'nd Edition, John Wiley.

FASE, M. M. G. and ABMA, R. C. N. (2003). Financial environment and economic growth in selected Asian countries. Journal of Asian Economics, 14(1), pp. 11-21

FAVARA, G. (2003). An Empirical Reassessment of the Relationship between Finance and Growth. International Monetary Fund Working Paper, 03/123, European I Department

Fung M. K (2009) Financial development and economic growth: Convergence or divergence? Journal of International Money and Finance 28(1): 56-67

GRAFF, M. (2001). Economies, political, and social conditions affecting the influence of financial activity on economic growth. Paper submission to SPIE 7 Annual conference

GRAFF, M. (2002). Causal Links Between Financial Activity and Economic Growth: Empirical Evidence from a Cross-Country Analysis, 1970-1990. Bulletin of Economic Research, 54, pp. 119-133

GRAFF, M. (2005). Socio-Economic Factors and the Finance-Growth Nexus. The European Journal of Finance, 11, pp. 183-205

GRANGER, C.W.J. (2003). Some aspects of causal relationships. Journal of Econometrics, 112, pp. 69-71

GREENE, W.H. (2003). Econometric Analysis. 2nd ed. Prentice-Hall

GREENWOOD, J. and BRUCE, S. (1997). Financial markets in development, and the development of financial markets. Journal of Economic Dynamics and Control, 21(2), pp. 145-181

GREENWOOD, J. and SMITH, B. (1997). Financial markets in development, and the development of financial markets. Journal of Economic Dynamics and Control, 21(1), pp. 145-181 
GREGORIO, J.D. and GUIDOTTI P, E. (1995). Financial development and economic growth. World Development, 23(3), pp. 433-448

GRIES, T., KRAFT, M. and MEIERRIEKS, D. (2009). Linkages between financial deepening, trade openness, and economic development: Causality evidence from sub-Saharan Africa. World Development, 37(12), pp. 1849-1860

HARBERGER, AC. (1998). A Vision of the Growth Process. American Economic Review, 88, pp. 1-33

HERWARTZ, H. and WALLE, Y. M. (2014). Determinants of the link between financial and economic development: Evidence from a functional coefficient model. Economic Modelling, 37(2), 417-427

HICKS, J. (1969). A theory of economic history. Oxford: Clarendon Press

HSUEH, S. J., HU, Y. H. and TU, C. H. (2013). Economic Growth and Financial Development in Asian Countries: A Bootstrap Panel Granger Causality Analysis. Economic Modeling, 32, pp. 294-301

HUANG, Y. (2011). Determinants of Financial Development. Palgrave Macmillan JALIL, A., FERIDUN, M. and MA, Y. (2010). Finance-growth nexus in China revisited: New evidence from principal components and ARDL bounds tests. International Review of Economics and Finance, 19(2), pp. 189-195

KAMINSKY, GL. and REINHART, CM. (1999). The twin crises: the causes of banking and balance-of- payments problems. The American Economic Review (Evanston), 89(03), pp. 473500

KAR, M., NAZLIOGLU, S. and AGIR, H. (2011). Financial development and economic growth nexus in the MENA countries: Bootstrap panel granger causality analysis. Economic Modelling, 28, pp. 685-693

KHAN, M. and SENHADJI, A. (2003). Financial Development and Economic Growth: A Review and New Evidence. Journal of African Economies, 12(1), pp. ii89-ii110

KING, R. and LEVINE, R. (1993a) Finance and growth: Schumpeter might be right. The Quarterly Journal of Economics, 108(3), pp. 717-737

KING, R. and LEVINE, R. (1993b). Finance, entrepreneurship and economic growth: Theory and evidence. Journal of Monetary Economics, 32(3), pp. 513-542

KIRKPATRICK, C. (2000). Financial Development, Economic Growth and Poverty Reduction. Mahboob Ul Haq Memorial Lecture at 16th AGM of PSDE, January

KÓNYA, L. (2006). Exports and growth: Granger causality analysis on OECD Countries with a panel data approach. Economic Modelling, 23, 978-992

LEVINE, R. and ZERVOS, S. (1998). Stock markets, banks and economic growth. American Economic Review, 88(3), pp. 537-558

LIANG, Q. and TENG, J.Z. (2006). Financial development and economic growth: evidence from China. China Economic Review, 17(4), pp. 395-411

MARK, N.C., OGAKI, M. and SUL, D. (2005). Dynamic seemingly unrelated cointegrating regression. Review of Economic Studies, 72, pp. 797-820

MCKINNON, R.I. (1973). Money and capital in economic development. Washington, DC: Brookings Institution

MENYAH, K., NAZLIOGLU, S. and WOLDE-RUFAEL, Y. (2014). Financial development, trade openness and economic growth in African countries: New insights from a panel causality approach. Economic Modelling, 37, pp. 386-394

MURINDE, V. (2012). Financial development and economic growth: global and African experience. Journal of African Economies, 21, pp. i10-i56

NACEUR, S. B. and GHAZOUANI, S. (2007). Stock markets, banks, and economic growth: Empirical evidence from the MENA region. Research in International Business and Finance, 21(2), 297-315 
NAZLIOGLU, S., LEBE, F. and KAYHAN, S. (2011). Nuclear Energy Consumption and Economic Growth in OECD Countries: Cross-sectionally Dependent Heterogeneous Panel Causality Analysis. Energy Policy, 39, pp. 6615-6621

ODHIAMBO, N.M. (2008). Financial depth, savings and economic growth in Kenya: a dynamic casual relationship. Economic Model, 25(4), pp. 704-713

ODHIAMBO, N.M. (2010).Finance-investment-growth nexus in South Africa: an ARDL bounds testing procedure. Economic Change and Restructuring, 43, pp. 205-219

PESARAN, M.H. (2004). General Diagnostic Tests for Cross Section Dependence in Panels. CESifo Working Paper 1229, IZA Discussion Paper 1240

PESARAN, M.H. (2006). Estimation and inference in large heterogeneous panels with multifactor error structure. Econometrica, 74 (4), pp. 967-1012

PESARAN, M.H. and YAMAGATA, T. (2008). Testing slope homogeneity in large panels. Journal of Econometrics, 142, pp. 50-93

PESARAN, M.H., ULLAH, A. and YAMAGATA, T. (2008). A bias-adjusted LM test of error cross section independence. Econometrics Journal, 11, pp.105-127

PRADHAN, R. P. (2013). The determinants of long-run finance development: The ARDL bound testing approach. Journal of Social and Management Sciences, 52(1), pp. 43-63

PRADHAN, R. P., ARVIN, M. B., NORMAN, N. R. and NISHIGAKI, Y. (2014). Does banking sector development affect economic growth and inflation? A panel cointegration and causality approach. Applied Financial Economics, 24(7), pp.465-480

PRADHAN, R. P., DASGUPTA, P. and SAMADHAN, B. (2013). Finance development and economic growth in BRICS: A panel data analysis. Journal of Quantitative Economics, 11(1 2), pp. 308-322

RAJAN, R. and ZINGALES, L. (1998). Financial dependence and growth. American Economic Review, 88(3), pp. 559-586

ROUSSEAU, P. L. and WACHTEL, P. (1998). Financial Intermediation and Economic Performance: Historical Evidence from Five Industrialized Countries. Journal of Money, Credit and Banking, 34, pp. 657-678

ROUSSEAU, P. L. and WACHTEL, P. (2011). What is happening to the impact of financial deepening on economic growth? Economic Inquiry, 49(1), pp. 276-288

SARAFIDIS, V. and ROBERTSON, D. (2009). On the impact of error cross-sectional dependence in short dynamic panel estimation. Econometrics Journal, 12, pp. 62-81

SCHUMPETER, J. A. (1934). Theorie der Wirtschaftlichen Entwickiung [The theory of economic development]', Leipzig: Dunker\& Humblot, 1912; translated by Redvers Opie. Cambridge, MA: Harvard U. Press

SCHUMPETER, J. A. (1911). The theory of economic development. Harvard University Press, Cambridge, MA

SHAW, E. S. (1973). Financial Deepening in Economic Development. Oxford University Press, New York

SMITH, A. (1960). The Wealth of Nations, Introduction by Seliqman. E.R.A. Dent, London, 1776

SWAMY, P.A.V.B. (1970). Efficient inference in a random coefficient regression model. Econometrica, 38, pp. 311-323

THORNTON, J. (1994). Financial deepening and economic growth: Evidence from Asian economies. Savings and Development, 18(1), pp. 41-51

UDDIN, G. S., SHAHBAZ, M., AROURI, M. and TEULON, F. (2014). Financial development and poverty reduction nexus: A cointegration and causality analysis in Bangladesh. Economic Modelling, 36(1), pp. 405-412

WACHTEL, P. (2003). How Much Do We Really Know about Growth and Finance? Economic Review, 88, pp. 33-48 
WOLDE-RUFAEL, Y. (2009). Re-examining the financial development and economic growth nexus in Kenya. Economic Modelling, 26(6), pp. 1140-1146

WU, J., HOU, H. and CHENG, S. (2010). The dynamic impacts of financial institutions on economic growth: Evidence from the European Union. Journal of Macroeconomics, 32(3), pp. 879-891.

\section{APPENDIX: DATA AND SOURCES}

The banking system's share of GDP is computed from various issues of the UN NATIONAL ACCOUNT STATISTICS, New York, referring to 'finance, insurance and business services' The number of Banks and branches are counted from the corresponding editions of the BANKERS' ALMANAC AND YEARBOOK, London: Thomas Skinner; labor force data (for normalization) are from ILO and included in the PENN WORLD TABLES

The share of labor employed in the banking system is taken from various issues the ILO YEARBOOK OF LABOUR STATISTICS, Geneva. The corresponding ISIC-2 ('international standard industrial classification of all economic activities', 1968) classification is 'majordivision 8' (financial institutions, insurance, real estate and business services). 